\title{
POTENSI ANTIBAKTERI EKSTRAK DAGING BUAH KELUBI (Eleiodoxa conferta) BANGKA BELITUNG MENGGUNAKAN MICROWAVE-ASSISTED EXTRACTION (MAE)
}

\author{
Antibacterial Potential of Kelubi Fruit Meat Extract (Eleiodoxa conferta) Bangka \\ Belitung Using Microwave-Assisted Extraction (MAE)
}

\author{
Surtina, Ratih Puspita Sari, Zulita, Rani, Occa Roanisca, Robby Gus Mahardika* \\ Department of Chemistry, Faculty of Engineering, Universitas Bangka Belitung \\ Kampus Terpadu UBB, Balunijuk, Merawang, Kabupaten Bangka, Kepulauan Bangka Belitung \\ *Corresponding author, e-mail: robby@ubb.ac.id
}

Received: Jul. 2019 Published: Jan. 2020

\begin{abstract}
Antibacterial tests were carried out using ethanol extract of kelubi meat (Eleidoxa conferta), extraction using the Microwave-Assisted Extraction method with a ratio of 2: 20 for 30 minutes at $60{ }^{\circ} \mathrm{C}$. Antibacterial tests using diffusion methods with concentrations of $20 \%, 40 \%, 60 \%, 80 \%$, and $100 \%$; positive control of $0.005 \%$ amoxillin and DMSO negative control. Antibacterial test results showed that the inhibition zone of ethanol extract in E. coli bacteria with a concentration of $20 \%$ was in the moderate category, for a concentration of $40 \%$ including the strong category while the concentration of $60 \%, 80 \%$ and $100 \%$ was very strong. The inhibition zone of ethanol extract for the $S$. aureus bacterium with a concentration of $20 \%$ is included in the strong category while the concentration of $40 \%, 60 \%, 80 \%$, and $100 \%$ is categorized as very strong. From these results it can be concluded that the inhibitory zone in Stapylococcus aureus bacteria is greater than that of E. coli bacteria.
\end{abstract}

Keywords: Kelubi, Microwave-Assisted Extraction, Extracts, antibacterials.

\section{PENDAHULUAN}

Di Indonesia banyak terdapat tumbuhan yang memiliki buah yang rasanya masam sehingga dikenal dengan nama asam salah satunya yaitu kelubi. Biasanya buah kelubi bisa dikonsumsi tanpa diolah sebagai bahan makanan seperti pada makanan khas Bangka yaitu lempah kuning. Kelubi bisa memberikan rasa asam yang merupakan ciri khas dari makanan tersebut serta kelubi juga banyak diolah menjadi manisan. Kelubi merupakan sejenis salak hutan yang termasuk kedalam Genus Eleiodoxa dan famili Arecaceae dengan nama ilmiah (Eleiodoxa conferta) (Lim, 2012).

Kelubi atau asam paya banyak tumbuh dilingkungan lembab hutan berpayau di tepi sungai atau rawa. Kelubi banyak ditemukan di wilayah Malaysia dan Indonesia (khususnya Sumatera) (Lim, 2012). Kelubi merupakan tanaman yang mirip dengan tanaman nipah (Nypa fruticans) yang dapat mencapai ketinggian maksimal hingga 5 meter. Ciri daunnya mempunyai warna hijau lurus dengan susunan saling berhadapan dengan panjang sekitar 1,5 m dan lebar sekitar 3-5 cm. Pelepah daun keluar dari batang perdu dan dapat mencapai 3-4 meter. Pelepah daun ditutupi oleh duri dengan panjang antara 5-7 meter. Ppelepah akan mati setelah ketiak pelepah mengeluarkan bunga dan daun. Akar tanaman ini berupa akar serabut, dan antar batang tumbuh rapat (Mohamad dkk., 2018).

Buah kelubi (Eleiodoxa conferta) telah dilaporkan mengandung $82,2 \%$ air, $0,8 \%$ protein, $3,1 \%$ lemak, $11,8 \%$ karbohidrat, $11,8 \%$ serat, dan kadar abu $0,7 \%$. Selain itu, buah kelubi juga mengandung mineral dan vitamin seperti K 227 $\mathrm{mg}$, Ca $26 \mathrm{mg}, \mathrm{Mg} 22 \mathrm{mg}, \mathrm{P} 10 \mathrm{mg}$, Fe 5,5 mg, Zn 8,9 ppm, Mn 5 ppm, Cu 2,9 ppm, dan vitamin C 0,6 mg (Lim, 2012). Buah kelubi (Eleiodoxa conferta) ini juga dilaporkan mengandung antosianin dalam ekstrak etanol dan digunakan sebagai dye-sensitized solar cells (DSSCs) dengan efisiensi 1,00\% (Jaafar dkk., 2018).

Uji fitokimia ekstrak kasar metanol dari Eleiodoxa conferta dilaporkan mengandung flavonoid, fenolik, dan saponin. Ekstrak kasar ini 
bersifat sangat kuat sebagai antioksidan dengan nilai $\mathrm{IC}_{50}$ sebesar $26,828 \mu \mathrm{g} / \mathrm{mL}$ (Afriani dkk., 2014). Mokhtar dan Aziz, (2015) melaporkan air buah kelubi mengandung tiga asam organik yaitu asam malat, asam oksalat, dan asam askorbat. Air buah kelubi ini mempunyai sifat antibakteri terhadap bakteri $S$. aureus (zona hambat 10,7 $\mathrm{mm})$, B. cereus (zona hambat $11,3 \mathrm{~mm}$ ), E. coli (zona hambat $12,7 \mathrm{~mm}$ ), P. Aeruginosa (zona hambat $8,7 \mathrm{~mm}$ ) dan Salmonella spp (zona hambat $10,3 \mathrm{~mm}$ ). Sedangkan ekstrak kasar etanol dilaporkan memiliki zona hambat $S$. aureus 9,63 mm dan S. thypi 17,61 mm (Safitri dkk., 2017). Baik air atau ekstrak kasar etanol buah kelubi telah dilaporkan bersifat antibakteri. Tetapi berdasarkan penelitian tersebut ekstraksi terhadap buah kelubi yang dilaporkan menggunakan blander maupun dengan perendaman atau maserasi. Metode ekstraksi yang dilakukan membutuhkan 1-4 hari untuk mendapatkan ekstrak buah kelubi. Sehingga perlu adanya efisiensi ekstraksi buah kelubi mengingat kebutuhan dan pengembangan antibakteri masih perlu dilakukan karena hal penyebaran penyakit, infeksi dan resistensi akan antibakteri yang terus meningkat (Kresse dkk., 2007).

Salah satu metode ekstraksi yang efisien yaitu kombinasi panas dengan gelombang mikro dengan menggunakan Microwave-Assisted Extraction (MAE) (Mahardika dan Roanisca, 2019) (Mandal dkk., 2007). Jika meserasi membutuhkan waktu lebih dari 24 jam, ekstraksi dengan MAE hanya membutuhkan beberapa menit saja. Selain itu metode MAE tidak membutuhkan banyak pelarut (Enggiwanto dkk., 2018). Oleh sebab itu perlu dilakukan pengembangan antibakteri ekstrak Eleiodoxa conferta menggunakan Microwave-Assisted Extraction (MAE).

\section{METODOLOGI}

Alat

Aluminium foil, Kertas cakram, Botol sampel, Microwave Assisted Extaction (MAE), corong, neraca analitik, blender, rotary evaporator, oven, plastik sampel, kertas saring, tabung reaksi, cawan petri, jangka sorong, pipet mikro, bunsen

\section{Bahan}

Daging Buah Kelubi, $\mathrm{FeCl}_{3}$, Aquades, Etanol, Alkohol, Kloroform, Pereaksi Wagner, Asam Asetat Glasial, Pereaksi Mayer, Bakteri
Staphylococcuaureus, Bakteri E. coli, $\mathrm{H}_{2} \mathrm{SO}_{4}$, DMSO

\section{Prosedur Kerja \\ Preparasi Sampel}

Sampel penelitian ini merupakan daging buah kelubi (Eleiodoxa conferta) yang diambil dari Desa Pergem, Air Gegas, Bangka Selatan. Sampel dikeringkan diudara terbuka selama 5 hari, setelah itu digiling dengan blender dan diayak. Serbuk dengan ukuran $<0,2 \mathrm{~mm}$ melalui tahap selanjutnya yaitu ekstraksi, sedangkan ukuran serbuk $<0,2 \mathrm{~mm}$ diblender kembali (Roanisca dkk., 2019)

\section{Ekstraksi Senyawa Aktif dan Karakterisasi Pelarut}

Serbuk kering buah kelubi (Eleiodoxa conferta) diambil 2-gram dimasukan $20 \mathrm{~mL}$ pelarut dalam tabung microwave. Microwave yang digunakan adalah MARS 6 dari CEM (Gambar 1). Tabung (vessel) yang digunakan adalah EasyPrep plus berbahan teflon (Gambar 2). Pelarut yang digunakan pada penelitian ini adalah etanol. Masing-masing pelarut digunakan tabung microwave. Tabung selanjutnya dimasukkan dalam Microwave-Assisted Extraction (MAE) pada suhu dan pewer $60^{\circ} \mathrm{C}$ dan 1200 W dengan Ramp 20 menit dan hold 10 menit. Ekstrak dipisahkan dari residu dengan kertas saring. Ekstrak yang didapatkan kemudian dipekatkan menggunakan rotary evaporator vacuum hingga didapatkan ekstrak pekat (Dahmoune, 2015).

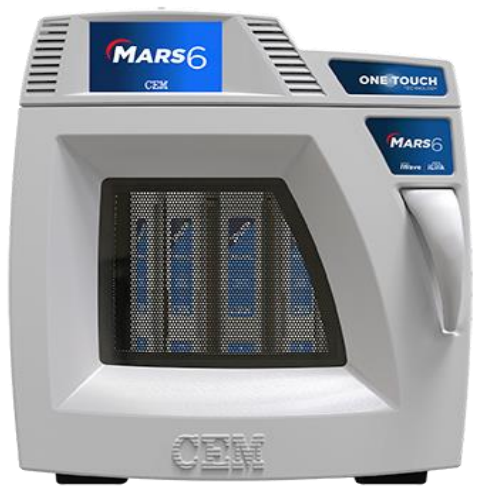

Gambar 1. MARS 6 dari CEM Corporation

\section{Uji Antibakteri}

Uji aktivitas antibakteri dilakukan terhadap ekstrak hasil Microwave Assisted Extraction (MAE). Pengujian dilakukan terhadap jenis bakteri gram (+) dan gram (-) yaitu $S$. aureus dan 
E. coli. Pengujian ini dilakukan dengan difusi agar pada masing-masing hasil ekstraksi dan partisi diuji dalam berbagai konsentrasi sebanyak 20\%, 40\%, 60\%, 80\% dan 100\%; kontrol positif $0,05 \%$ amoxillin dan kontrol negatif DMSO 1 $\mathrm{mL}$. Selanjutnya cawan petri yang berisi bakteri $S$. aureus dan E. coli yang telah diinokulasikan sebanyak 2 ose diinkubasi pada suhu $37^{\circ} \mathrm{C}$ selama 24 jam. Kemudian diamati pertumbuhan bakteri dan diukur diameter zona hambatannya dengan menggunakan jangka sorong (Miranti dkk.,2013).

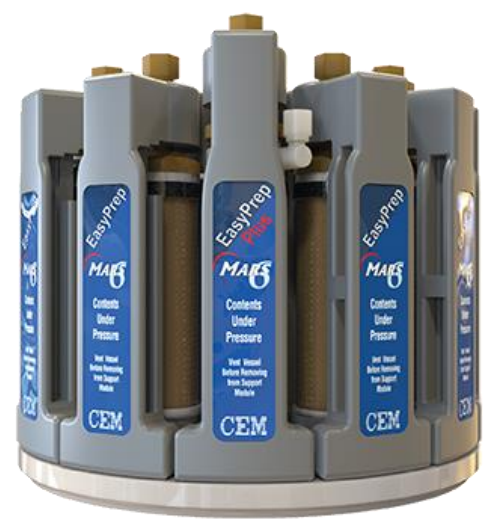

Gambar 2. Tabung (vessel) yang digunakan untuk MAE

\section{HASIL DAN PEMBAHASAN}

\section{Preparasi Sampel}

Buah Kelubi di kupas dan dipisahkan dari bijinya. Setelah itu dilakukan penjemuran dibawah sinar matahari selama 5 hari hingga tidak terdapat lagi kadar air dan selanjutnya diblander hingga halus (Atisanto dkk., 2017).

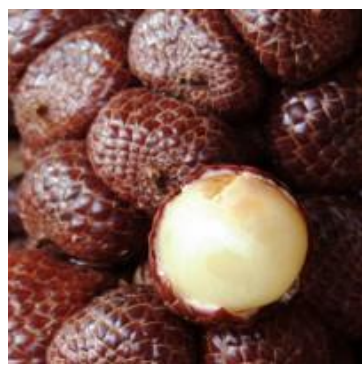

(a)

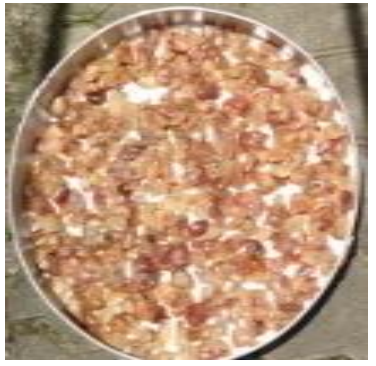

(b)
Gambar 3. (a) Buah kelubi segar; (b) Buah kelubi kering

Preparasi sampel dilakukan untuk membuat sampel buah kelubi menjadi serbuk yang siap pakai (Gambar 3). Pembuatan sampel menjadi serbuk untuk memudahkan dalam ekstraksi yang dilakukan dengan metode Microwave-Assisted Extraction.

\section{Ekstraksi}

Ekstraksi yang dilakukan pada penelitian ini menggunakan metode Microwave Assisted Extraction (MAE) pada suhu $60^{\circ} \mathrm{C}$ dan power $1200 \mathrm{~W}$ dengan waktu Ramp 20 menit dan hold 10 menit. Setelah dilakukan ekstraksi kemudian ekstrak tersebut di evaporasi dengan rotary evaporator dengan suhu $60^{\circ} \mathrm{C}$ hal ini bertujuan untuk menghilangkan pelarut yang digunakan pada saat ekstraksi. Ekstrak yang telah dievaporasi yang awalnya berupa larutan menjadi kental. Hasil evaporasi didapatkan ekstrak kental berwarna merah kecokelatan dengan rendemen $34,766 \%$ (Gambar 4).

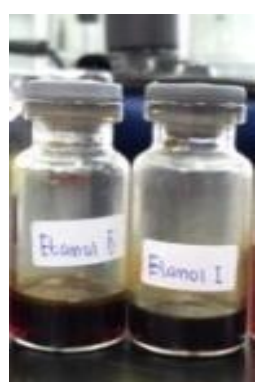

Gambar 4. Hasil Ekstraksi menggunakan MAE

\section{Uji Antibakteri}

Ekstrak etanol daging buah kelubi memiliki aktivitas antibakteri terhadap bakteri $S$. aureus dan bakteri $E$. coli ditandai dengan terbentuk zona hambat (Gambar 5). Pada umumnya hubungan konsentrasi dan zona hambat berbanding lurus, semakin besar konsentrasi sampel maka zona hambat yang terbentuk semakin besar juga.

Data pengukuran zona hambat pertumbuhan bakteri $S$. aureus dan bakteri $E$. coli menggunakan ekstrak etanol buah kelubi disajikan pada Tabel 1 . Berdasarkan penelitian Lestari dan Ardiningsih (2016), kategori zona hambat antibakteri sebagai berikut: zona hambatan $20 \mathrm{~mm}$ atau lebih termasuk sangat kuat, $10-20 \mathrm{~mm}$ termasuk kuat, 5-10 mm termasuk sedang dan $5 \mathrm{~mm}$ atau kurang termasuk lemah.

Dari kategori tersebut maka dapat diketahui bahwa zona hambat ekstrak etanol untuk bakteri S. aureus dengan konsentrasi $20 \%$ termasuk kategori kuat sedangkan untuk konsentrasi $40 \%$, $60 \%, 80 \%$, dan $100 \%$ termasuk kategori sangat kuat dan bakteri E. coli dengan konsentrasi $20 \%$ dan $40 \%$ termasuk dalam kategori kuat sedangkan konsentrasi $60 \%, 80 \%, 100 \%$ termasuk kategori 
Surtina dkk. / Indo. J. Chem. Res., 2020, 7(2), 177-182

Tabel 1. Hasil diameter zona hambat

\begin{tabular}{|c|c|c|c|c|c|c|}
\hline \multirow[b]{2}{*}{ Bakteri uji } & \multirow{2}{*}{$\begin{array}{c}\text { Konsentrasi } \\
\text { Ekstrak Buah } \\
\text { Kelubi }\end{array}$} & \multicolumn{2}{|c|}{ Ulangan $(\mathrm{mm})$} & \multirow[b]{2}{*}{ Total } & \multirow[b]{2}{*}{$\begin{array}{l}\text { Rata-rata } \\
(\mathrm{mm})\end{array}$} & \multirow[b]{2}{*}{ Kategori } \\
\hline & & I & II & & & \\
\hline \multirow{7}{*}{$\begin{array}{l}\text { Stapylococcus } \\
\text { aureus }\end{array}$} & $20 \%$ & 19,64 & 19,64 & 38,64 & 19,64 & Kuat \\
\hline & $40 \%$ & 20,21 & 20,21 & 40,42 & 20,21 & Sangat kuat \\
\hline & $60 \%$ & 21,06 & 21,06 & 42,12 & 21,06 & Sangat kuat \\
\hline & $80 \%$ & 25,66 & 25,66 & 50,33 & 25,66 & Sangat kuat \\
\hline & $100 \%$ & 26,17 & 26,17 & 52,35 & 26,17 & Sangat kuat \\
\hline & $\mathrm{K}(+)$ & 29,16 & 29,16 & 58,32 & 29,32 & Sangat kuat \\
\hline & $\mathrm{K}(-)$ & 0 & 0 & 0 & 0 & - \\
\hline \multirow{7}{*}{ Escherichia coli } & $20 \%$ & 10,61 & 10,86 & 20,47 & 10,73 & Kuat \\
\hline & $40 \%$ & 12,70 & 11,61 & 24,31 & 12,15 & Kuat \\
\hline & $60 \%$ & 15,83 & 17,52 & 33,35 & 16,67 & Sangat kuat \\
\hline & $80 \%$ & 16,02 & 18,14 & 34,16 & 17,08 & Sangat kuat \\
\hline & $100 \%$ & 19,26 & 18,69 & 37,95 & 18,97 & Sangat kuat \\
\hline & $\mathrm{K}(+)$ & 21,28 & 22,54 & 43,82 & 21,91 & Sangat kuat \\
\hline & $\mathrm{K}(-)$ & 0 & 0 & 0 & 0 & - \\
\hline
\end{tabular}

Ket: $\mathrm{K}(+)=$ kontrol positif $($ amoxillin $) ; \mathrm{K}(-)=$ kontrol negatif $(\mathrm{DMSO})$

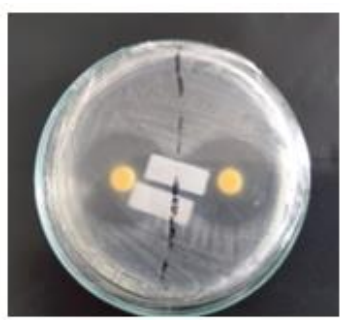

(a)

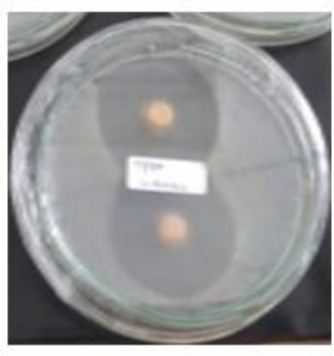

(c)

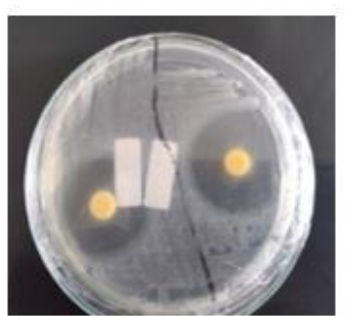

(b)

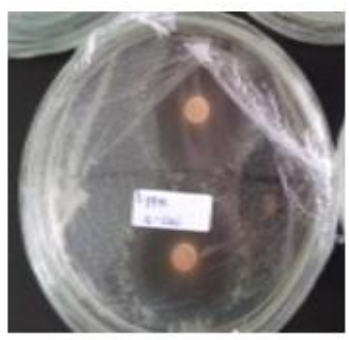

(d)

Gambar 5. (a) Zona hambat S. aureus 40\%, (b) Zona hambat E. coli 40\%, (c) Kontrol positif $S$. aureus (d) Kontrol positif E. coli

sangat kuat. Dari hasil di atas dapat diketahui bahwa ekstrak etanol daging buah kelubi memiliki aktivitas antibakteri pada bakteri $S$. aureus dan E. coli. Menurut Sari dkk., (2019) kandungan fitokimia pada air kelubi mengandung senyawa alkaloid, fenol hidrokuinon, saponin, dan flavonoid. Sedangkan steroid tidak ditemukan pada air buah kelubi yang berasa asam. Hal ini menunjukkan bahwa sangat kuatnya aktivitas daya hambat bakteri $S$. aureus dan E. coli diduga disebabkan adanya senyawa fenolik dan alkaloid.

Hasil pengujian menunjukkan bahwa zona hambat bakteri $S$. aureus lebih besar dibandingkan dengan zona hambat bakteri E. coli. Hal ini dikarenakan $S$. aureus termasuk dalam bakteri gram positif yang dimana memiliki dinding sel yang lebih sederhana dibandingkan bakteri gram negatif seperti $E$. coli. Oleh sebab 
itu, senyawa antibakteri lebih mudah masuk ke dalam bakteri gram positif (Connel dkk., 2013).

Berdasarkan penelitian sebelumnya, air buah kelubi (Eleiodoxa conferta) yang diekstrak menggunakan blander memiliki zona hambat bakteri S.aureus sebesar 10,7 $\mathrm{mm}$ dan E. coli sebesar 12,7 mm (Mokhtar dan Aziz, 2015). Zona hambat ini lebih rendah jika dibandingkan ekstrak etanol menggunakan MAE. Selain itu, menurut Safitri dkk., (2017) ekstrak etanol hasil maserasi buah kelubi (Eleiodoxa conferta) pada konsentrasi $80 \%$ memiliki zona hambat $S$. aureus sebesar 9,63 mm. Maserasi ini dilaporkan selama 4 hari. Hal ini menunjukkan bahwa dengan pelarut yang sama, aktivitas antibakteri ekstrak MAE lebih baik jika dibandingkan dengan ekstrak maserasi atau hasil blander. Adanya radiasi gelombang mikro dari microwave dapat membantu memecah dinding sel khususnya dari buah kelubi tersebut sehingga difusi pelarut lebih mudah masuk ke dalam sel dan melarutkan senyawa aktif didalamnya (Mahardika dan Roanisca, 2019). Di sisi lain waktu ekstraksi dengan MAE lebih singkat jika dibandingkan dengan maserasi. Hal ini yang membuat MAE lebih efisien dibandingkan maserasi.

\section{KESIMPULAN}

Ekstrak daging buah kelubi memiliki potensi antibakteri terhadap bakteri S. aureus dan E. coli, Rata-rata zona hambat ekstrak etanol untuk bakteri S. aureus untuk konsentrasi 20\%; 19,64 $\mathrm{mm}$ termasuk kategori kuat sedangkan untuk konsentrasi $40 \%, 60 \%, 80 \%$, dan $100 \%$ secara berurutan yaitu $20,12 \mathrm{~mm} ; 21,06 \mathrm{~mm} ; 25,665$ $\mathrm{mm} ; 26,175 \mathrm{~mm}$ termasuk kategori sangat kuat dan bakteri E. coli dengan konsentrasi 20\%; $10,735 \mathrm{~mm}$ dan $40 \%, 12,155 \mathrm{~mm}$ termasuk dalam kategori kuat sedangkan konsentrasi $60 \%, 80 \%$, $100 \%$ secara berurutan $16,675 \mathrm{~mm} ; 17,08 \mathrm{~mm}$; $18,975 \mathrm{~mm}$ termasuk kategori sangat kuat. Hal ini menunjukkan bahwa antibakteri ekstrak etanol daging buah kelubi bakteri $S$. aureus lebih bagus di bandingkan bakteri E. coli

\section{UCAPAN TERIMA KASIH}

$\begin{array}{lcr}\text { Peneliti } & \text { berterimakasih } & \text { kepada } \\ \text { Kemenristekdikti } & \text { Direktorat } & \text { Jendral } \\ \text { Pembelajaran dan Kemahasiswaan yang telah } \\ \text { memberikan bantuan dana penelitian berdasarkan } \\ \text { SK No. 1020/B3. 1/KM/2019 }\end{array}$

\section{DAFTAR PUSTAKA}

Afriani, S., Idiawati, N., Destiarti, L., Arianie, L., 2014, Uji Aktivitas Antioksidan Daging Buah Asam Paya (Eleiodoxa conferta Burret) Dengan Metode DPPH dan Tiosianat, J. Kimia Khatulistiwa, 3(1), 4956.

Atisanto, S. V., Mulyani, S., Triani, I.G. A. L., 2017, Pengaruh jenis pelarut dan suhu pengeringan terhadap karakteristik ekstrak pada buah kelubi (Eleiodoxa conferta), Jurnal Dari Rekayasa Dan Manajemen Agroindustri, 5(3), 35-44.

Connell, K. M. G. O., Hodgkinson, J. T., Sore, H. F., Welch, M., Salmond, G. P. C., Spring, D. R., 2013, Combating Multidrug-Resistant Bacteria: Current Strategies for the Discovery of Novel Antibacterials, Angew. Chem. Int., 52(41), 2-30.

Dahmoune, F., 2015, Optimization of microwaveassisted extraction of polyphenols from $M$. communis L. leaves, Food Chemistry, 166, 585-595.

Enggiwanto, S., Istiqomah, F., Daniati, K., Roanisca, O., Mahardika, R. G., 2018, Ekstraksi Daun Pelawan (Tristaniopsis merguensis) Sebagai Antioksidan Menggunakan Microwave-Assisted Extraction ( MAE ). Indonesian Journal of Pure and Applied Chemistry, 1(2), 50-55.

Hemwimon, S., Pavasant, P., Shotipruk, A., 2007, Microwave-assisted extraction of antioxidative anthraquinones from roots of Morinda citrifolia. Separation and Purification Technology, 54(1), 44-50.

Jaafar, H., Ain, M. F., Ahmad, Z. A., 2018, Performance of $E$. conferta and $G$. atroviridis fruit extracts as sensitizers in dyesensitized solar cells ( DSSCs ), Ionics, 24, 891-899.

Kresse, H., Belsey, M. J., Rovini, H., 2007, The antibacterial drugs market. Nature Reviews Drug Discovery, 6(January), 19-20.

Lestari, Y., Ardiningsih, P., 2016, Aktivitas Antibakteri Gram Positif Dan Negatif Dari Ekstrak Dan Fraksi Daun Nipah ( Nypa fruticans Wurmb.), Jurnal Kimia Katulistiwa, 5(4), 1-8.

Lim, T. K., 2012, Scientific Name. In Edible Medicinal and Non-Medicinal Plants, 1, 396-398.

Mahardika, R. G., Roanisca, O., 2019, Microwave-Assisted Extraction of 
Polyphenol Content from Leaves of Tristaniopsis merguensis. ASEAN Journal of Chemical Engineering, 19(2), 110-119.

Mandal, V., Mohan, Y., Hemalatha, S., 2007, Microwave-Assisted Extraction- An Innovative and Promosing Extraction Tool for Medicinal Plant Research. Pharmaconosy Reviews, 1, 7-18.

Miranti, M., Prasetyorini., Suwary, C., 2013, Perbandingan aktivitas antibakteri ekstrak etanol 30\% dan 96\% kelopak bunga rosella (Hibiscus sabdariffa) terhadap bakteri $S$. aureus, Ekologia, 13(1), 9-18

Mohamad, N. I., Manan, M. A., Abdullah Sani, N., 2018, Antibacterial potential of lactic acid bacteria isolated from local pickled Eleiodoxa conferta (kelubi) against selected foodborne pathogens. Malaysian Journal of Microbiology, 14(6), 490-496.

Mokhtar, S. I., Aziz, N. A. A., 2015, Organic Acid Content and Antimicrobial Properties of Eleiodoxa conferta Extracts at Different Maturity Stages, J. Trop. Resour. Sustain. Sci., 3, 72-76.
Roanisca, O., Mahardika, R. G., Setiawan, Y., 2019, Tristaniopsis merguensis Griff. Extract as Inhibitor for Corrosion of Stainless Steel. IOP Conference Series: Earth and Environmental Science, 353 012020.

Safitri, G. L., Wibowo, M. A., Idiawati, N., 2017, Uji Aktivitas Antibakteri Ekstrak Kasar Buah Asam Paya (Eleiodoxa conferta (Griff.) Buret) Terhadap Bakteri Staphylococcus Aureus Dan Salmonella Thypi, Jurnal Kimia Khatulistiwa, 6(1), 1720.

Sari, R. P., Surtina, Nazrun, Mahardika, R. G. (2019). Uji Fitokimia Dan Aktivitas Antibakteri Pada Air Kelubi (Eleiodoxa conferta ) Terhadap Bakteri Staphylococcus aureus, Seminar Nasional Penelitian Dan Pengabdian Pada Masyarakat III, 61-63. Pangkalpinang: Universitas Bangka Belitung. 